\title{
The Effect of Mobile Portfolio (M-Portfolio) Supported Mastery Learning Model on Students' Achievement and Their Attitudes towards Using Internet
}

\author{
Oguzhan Ozdemir ${ }^{1}$, Husamettin Erdemci ${ }^{2}$ \\ ${ }^{1}$ Firat University, Educational Faculty, Department of Computer Education and Instructional Technology, Elazig, \\ Turkey \\ ${ }^{2}$ Siirt University, Educational Faculty, Department of Computer Education and Instructional Technology, Siirt, Turkey \\ Correspondence: Oguzhan Ozdemir, Firat Universitesi, Egitim Fakultesi, A Blok, 130 Nolu Oda. Elazig, Turkey.
}

Received: January 5, 2017

doi:10.11114/jets.v5i3.2122
Online Published: February 6, 2017

URL: http://dx.doi.org/10.11114/jets.v5i3.2122

\begin{abstract}
The term mobile portfolio refers to creating, evaluating and sharing portfolios in mobile environments. Many of the states that pose an obstacle for portfolio usage are now extinguished through mobile portfolios. The aim in this research is to determine the effect of mobile portfolio supported mastery learning model on students' success and attitudes towards using internet. The research was carried out in the Academic Year 2014-2015 with students, taking Computer-I course at Primary School Teacher Education and Social Sciences Teaching Departments in Faculty of Education in Siirt University. The Internet Usage Attitudes Scale developed by Tavsancil \& Keser (2002), was used to determine student attitudes towards internet usage. The scale was prepared as a five point Likert type scale. An academic achievement test developed by researchers was used to determine achievement of course. The data analysis methods used in this study were average, standard deviation, independent groups t-test and dependent groups t-test. As a result of research, the effect of mobile portfolio supported mastery learning model on students' academic achievement was found to be positive. Furthermore, use of mobile portfolio among students tested in research, a positive increase was seen in their attitudes towards internet use. As a result of the data analysis, this difference shows no significant difference. According to the findings recommendations have been made.
\end{abstract}

Keywords: mobile, portfolio, m-portfolio, achievement, attitude

\section{Introduction}

Developments in the field of science and technology have led to a change in individual and social needs as well. These changes occurred in the field of education as well as other fields. All of the components in education were affected by the changes. Today, students are expected to be emotional and social individuals competent in questioning and researching. Similarly, teachers are expected to be agents who do not convey information to students as it is but rather as agents who guide the students in acquiring knowledge (Gunes, 2010; Cristophel, 1990).

Goals are determined during the educational process and all students are expected to attain these goals. It is quite difficult to carry out this in classrooms where there are students of various characteristics. In his studies, Bloom (2012) asserted that there are significant differences concerning achievement between one-to-one tutoring and group tutoring. Thus, Bloom searched the ways in attaining achievement of one-to-one tutoring in the classroom setting and developed the Mastery Learning Model (Senemoglu, 2012).

\subsection{Mastery Learning Model}

Education is the process of changing behaviors. Schools are the places where this process is operated with a plan and program. Giving education collectively brought about the problem of productivity. Various individual differences such as students' intelligence levels, language skills and understanding skills play a key role in causing this problem. What is expected from schools is to, despite these individual's differences, teach each student the same content in the same classroom setting during the same amount of time. The inevitable outcome of this expectation from the learning process is the achievement of intelligent and smart students and the failure of the other students. 
The Mastery Learning Model, which Bloom developed by claiming that every student can be successful, asserts that; unless there are no drawbacks, every student can learn under convenient conditions and when the right amount of time is spared (Senemoglu, 2012). Mastery learning is a learning model that puts emphasis on individual manners, tolerates individual differences, and requires students to complete one unit before moving on to a next unit (Rani, 2016). The difference in learning levels of people is due to environmental factors and the teaching-learning feature of schools rather than innate characteristics. There are many factors which affect student achievement. Some of these factors are inherent. For example, intelligence level and language skills are among these characteristics. There are also environmental factors which affect student achievement. The socio-economic state of the family, the environment where the student is raised and characteristics of the teacher are environmental factors which affect student achievement (Guskey, 1997). There are no operations that can be carried out in schools against some of these factors. Increasing the intelligence level of students or changing their socio-economic conditions is not a function of schools. Similarly, schools don't have the responsibility of changing the individual characteristics of students. Teachers have various functions in schools such as identifying pre-learning status of students, enabling the students to develop positive attitudes towards the course and promote an interest towards the course (Aderemi, 2006). The most important feature of Mastery learning is that students can progress at their own rate (Senemoglu, 2012).

The Mastery Learning Method has three main variables in optimizing the effectiveness and productivity of schools. Two of these variables are related to student qualifications and the other is related to instruction. The instructional output is the dependent variable of this equation.

The goal of mastery learning is identifying the factors which affect student achievement and control them and optimize students' levels of learning. It is evident on the scheme that there are three factors which affect students' learning levels or the instructional outputs (Bloom, 2012).

1) The preliminary knowledge required for students to learn target behaviors

2) The desire and attitudes of students towards the course and the effort the student puts in for the sake of learning

3) The course being convenient for student demands and the comprehendability, effectiveness and competence of the course

Cognitive entry behaviors are the students' initial states which determine student achievement and learning levels. Cognitive entry behaviors are defined as the knowledge required for a student to learn a new subject. It is crucial to determine the preliminary knowledge, in other words the cognitive entry behaviors, of students while teaching a new subject. The Mastery Learning theory emphasizes that the student needs to sufficiently have the preliminary knowledge when starting a new unit (Damavandi \& Kashani, 2010).

Affective entry behaviors are the state of student motivation towards the course. The motivational level of the student concerning the course is important in their learning (John \& Barchok, 2014). Thus, it is crucial that the subject should be clarified to the students and their interests towards the course should be aroused.

The quality of instructional service is a factor which determines students' learning levels and which are related to the instructional process. It consists of the process of using the required clues, reinforces and feedbacks. It is a process which clarifies the subjects that are to be learnt and how they are to be learnt. When these factors are positive, then the learning level is expected to be positive as well.

\subsubsection{Implementation of the Mastery Learning Model}

The basic stages of how the mastery learning model is implemented in schools are given below (Bloom, 2012; Senemoglu, 2012): Thus;

1) Target behaviors should be determined and how these behaviors are to be mastered should be clarified. A table of specifications should be prepared.

2) Prerequisite behaviors that are required for learning a new unit should be determined. The achievement criteria for students should be identified.

3) Cognitive entry tests should be conducted to identify whether or not students have the precondition behaviors. Mastery instruction should be carried out on students, who are determined to lack those behaviors based on the test results, so as to obtain the precondition behaviors.

4) Teaching-learning activities should be practiced in order to furnish the students with the behaviors in new units and observation tests should be conducted to determine the extent to which the students obtained the behaviors.

5) Additional instructional activities should be performed on students detected to have insufficient or wrong learning based on the observation tests. Enriched instructional activities should be conducted on students who have succeeded. 
6) After the additional instructional activities, observation tests are conducted on the students again to assess their acquisitions and whether or not the students attain the goals is determined. Additional activities are practiced for students who have failed to attain the goals.

7) After reaching the learning bench mark, the process continues by starting a new unit.

\subsection{Portfolio Assessment}

As an educational term, portfolio the collection of works of students gathered to determine their works, developments and achievements in a certain field, to observe their skills and talents and to evaluate them with the participation of their peers (Simon \& Forgette-Giroux, 2000). The Ministry of National Education (2009) defines portfolio as; a kind of evaluation and assessment method which reflects the works, performances and experiences of a student in one or more fields, which enables the teacher and parents to observe the student and which consists of classroom activities that promote an educational evaluation. The term portfolio is referred to as product selection file or product file in Turkish (Bahar et al, 2009).

Portfolios were implemented in their current forms initially in primary schools. This method, which was used in various courses, was soon started to be implemented in the upper stages of education (Davis \& Ponnamperuma, 2005). Portfolios are crucial because they are integrated with instructional curriculums and reflect classroom performance (Kutlu, Dogan \& Karakaya, 2014).

The main purpose of using portfolios is to underline the improvement of student achievement. This way, the individual developments of students were taken into consideration by observing their individual differences. According to Paulson and Meyer (As cited in Kutlu, Dogan \& Karakaya, 2014), the aims of portfolios are:

1) To objectively observe student development,

2) To development self-discipline and responsibility in students and to promote self-assessment skills in students,

3) To clearly display what the student has learnt,

4) Offer information and guidance for the future learning experiences of the student,

5) To display student skills and develop their areas of interest,

6) To teach the student about future team works by showing them the portfolios of their peers,

7) To go beyond the curriculum in verbal and written examinations and develop a new assessment method,

8) To help students to evaluate their own work,

9) To help the teacher in taking instructional decisions.

\subsection{Mobile Portfolio}

After starting to use technology in education, the solution of educational problems started to be carried out by resorting to technology. Technology is not used just as a problem solving tool. Technology is used in education in order to offer a more effective and productive instructional service (Alkan, 2011). Although mobile learning brings many opportunities for educators, it also has some barriers, one of which is to have access to such technologies (Gloria \& Oluwadara, 2016). Mobile learning is defined as the learning through a mobile device, it is also explained as learning process that occurs at any time and place (Jan et al., 2016). Technology is also used in education in order to solve various problems.

Using technology in education has a long history. The computer is the first that comes to mind when we talk about technology in education. However, every technological output is not convenient to be used in education. The radio, television and prior inventions have been used in education for years. However, because the computer is furnished with many of the other technological devices' features, it has taken their spot (Usun, 2006).

Portfolios have disadvantages along with their advantages. These disadvantages create drawbacks for portfolio usage, which has many advantages. One of these problems concerns the person who cannot access the outputs at the desired time and place for evaluation. This requires the teacher to be at a specific location at a specific time. One other drawback concerns the problem of archiving the outputs collected from students. This problem becomes even more serious when the classroom is crowded (Brown, 2002). One other problem is related to collecting the outputs. This stage requires the student and teacher to be together at a certain time, which limits the use of portfolios.

Despite the fact that portfolios have features which enable following student success and development, technology was resorted to extinguish the obstacles that prevented the use of portfolios and thus, the term electronic portfolio was introduced. Electronic portfolio refers to collecting, archiving and distributing the works of students in computers (Kan, 2011). E-portfolio, generally used in higher education, is not only gathering learning outcomes in a digital platform but also an opportunity for lecturers to assess one's effort on learning (Oner \& Adadan, 2016). However, because computers 
operate through electricity, they are not fully independent of space and time.

The most common and most rapid technology of our era is undoubtedly mobile technologies. Studies suggest that the number of mobile subscribers is above 70 million. This number is estimated to be higher than 3 billion worldwide (International Telecommunication Union, 2014). Due to the rapid development and expansion of mobile technologies, mobile forms of computer oriented applications have been created (Agca, 2013).

The term mobile portfolio refers to creating, evaluating and sharing portfolios in mobile environments. Many of the states that pose an obstacle for portfolio usage are now extinguished through mobile portfolios.

\subsection{Purpose of the Study}

It is suggested that the mastery learning model is beneficial for every student to attain their goals and that the portfolio method is beneficial in following the learning and development processes. Today, mobile devices, whose subscribers are increasing each day, can be used in educational settings. Portfolios have been used in electronic environments since a long time. All operations concerning portfolios were carried out through mobile devices by means of their features. Thus, it is expected that supporting the mastery learning model with mobile portfolio will lead to positive outcomes on the students' academic achievements. It is also expected that students will use the internet more frequently while creating portfolios and that this would lead to a positive change in student attitudes towards internet usage. With this respect, the following questions were directed throughout the study;

1) Does mobile portfolio assisted mastery learning model have any effects on the academic achievement levels of students?

2) Does the teaching method of the mobile portfolio assisted mastery learning model have any effects on students' attitudes towards internet usage?

\section{Method}

\subsection{Model of the Study}

The experimental design was used in this study, which aimed at determining student behaviors in creating mobile portfolios and the effects it has on students' academic achievement levels and their attitudes towards internet usage. The experimental design is a research design in which desired data are collected to determine the relationship between the cause and the affect under the control of the researcher (Karasar, 2013).

As the experimental design of the study, the pretest-posttest with a control group was used. There is at least one experimental group and one control group in this model. Objectivity is essential while forming the groups. Evaluations are carried out before and after the experiments for both the experiment and the control group so as to test the hypotheses. The pre-tests which are conducted before the experiment are crucial in identifying the characteristics of the groups. In order to collect sound data, results of the pre-tests are considered while creating and organizing the groups (Buyukozturk et al., 2008). The symbolic vie of the experimental model used in this study is displayed below:

\begin{tabular}{|c|c|c|c|c|}
\hline GD & $\mathrm{R}$ & $\mathrm{O} 1$ & $\mathrm{X}$ & $\mathrm{O} 3$ \\
\hline GK & $\mathrm{R}$ & $\mathrm{O} 2$ & & $\mathrm{O} 4$ \\
\hline \multicolumn{5}{|c|}{ D: Experimental Group } \\
\hline \multicolumn{5}{|c|}{ K: Control Group } \\
\hline \multicolumn{5}{|c|}{ R: neutrality of choosing of sample } \\
\hline \multicolumn{5}{|c|}{ O1 ve O3: Pretest and posttest assessment of experimental group } \\
\hline \multicolumn{5}{|c|}{$\mathrm{O} 2$ ve O4: Pretest and posttest assessment of control group } \\
\hline \multicolumn{5}{|c|}{$\mathrm{X}$ : Independent variable } \\
\hline
\end{tabular}

\subsection{Study Group}

The study group consists of 106 students who studied in the Department of Social Sciences Teaching and Department of Classroom Teaching in Siirt University Faculty of Education during the 2014-2015 academic year. There were 22 female and 28 male students in the Department of Social Sciences Teaching. There were 36 female and 20 male students in the Department of Classroom Teaching. The study group was selected based on the fact that the students' results from the academic achievement pre-test and results from the internet usage attitude scale pre-test were similar and that the mean rate of having smart devices were similar among these students.

While creating the groups, the following points were taken into consideration; 
- The pre-test results of students from the achievement test

- Students' pre-application scores of the attitude scale considering their internet usage

- Whether or not students have a mobile (smart) device

- The groups which the students wanted to join but balance between the groups was crucial.

In order to promote objectivity, the groups were created based on certain criterion. The final distribution of the experimental and control groups are given on Table 1.

Table 1. The distribution of students according to departments, groups and gender

\begin{tabular}{lllllll}
\hline & \multicolumn{3}{c}{ Experimental Group } & \multicolumn{3}{l}{ Control Group } \\
\cline { 2 - 7 } & Female & Male & Total & Female & Male & Total \\
\hline Department of Social studies education & 11 & 14 & 25 & 11 & 14 & 25 \\
Department of elementary education & 18 & 10 & 28 & 18 & 10 & 28 \\
Total & 29 & 24 & 53 & 29 & 24 & 53 \\
\hline
\end{tabular}

While creating the groups, the students were asked about whether or not they had mobile devices. The data are displayed on Table 2. Thus;

Table 2. The ownership of mobile devices of students

\begin{tabular}{llllll}
\hline & \multicolumn{2}{l}{ Department of Social studies education } & \multicolumn{2}{l}{ Department of elementary education } & \multirow{2}{*}{ Total } \\
\cline { 2 - 5 } & Female & Male & Female & Male & \\
\hline Have & 20 & 25 & 34 & 19 & 94 \\
Not have & 2 & 3 & 2 & 1 & 12 \\
Total & 22 & 28 & 36 & 20 & 106 \\
\hline
\end{tabular}

According to Table 2, with $89 \%$, the majority of the students studying in both the departments of Social Sciences Teaching and Classroom Teaching have mobile devices.

Other criteria that were taken into consideration while selecting the groups were the pre-test results that students obtained from the achievement test and the pre-application results that students obtained from the internet usage attitudes scale. The scores which the students obtained from the pre-application of the achievement test are given below:

\subsection{Data Collection Tools}

A 20 item list of acquisitions was prepared before conducting the test on computer hardware. Two expert instructors of the course were resorted to after preparing the list of acquisitions. The acquisition list was revised. In order to evaluate the acquisitions, 40 questions, in other words twice the number of acquisitions, were prepared. The internet and books about computer hardware were resorted to while preparing the questions. A table of specifications was prepared about whether or not the questions and the acquisitions contained the units. The instructors were consulted throughout the process in order to achieve content validity.

The test was also conducted on students who had taken this course the previous year. The data collected form the tests conducted on 84 students was analyzed and the test took its final form. Data collected from the tests that were conducted on the group with 36 female and 48 male students are given on Table 3.

Table 3. The results of pilot application of the academic achievement test.

\begin{tabular}{lc}
\hline & Academic achievement test \\
\hline Number of questions & 40 \\
Sample size of pilot application & 84 \\
Mean & 28.6 \\
Item discriminating power & 0.59 \\
Item difficulty & 0.54 \\
KR21 & 0.76 \\
Cronbach alpha & 0.79 \\
Standard Deviation & 7.05 \\
\hline
\end{tabular}

Based on the data collected from the tests, four questions, which had differential and difficulty values below or above a 
certain criterion, were removed from the test. The Cronbach alpha coefficient was 0.816 and the KR21 value was 0.77 after these questions were removed from the test.

The Internet Usage Attitudes Scale developed by Tavsancil and Keser (2002) was used to determine student attitudes towards internet usage. The scale was prepared as a five point Likert type scale. The Cronbach's Alpha reliability coefficient for the scale was 0.89 .

\subsection{Data Analysis}

The data collected at the beginning and at the end of the practice were analyzed through the SPSS 21 software. The data analysis methods used in this study were average, standard deviation, independent groups t-test and dependent groups t-test.

\section{Findings and Interpretation}

The results of independent samples $t$ test of academic achievement pretest of experimental and control groups given in table 4.

Table 4. The results of independent samples $t$ test of academic achievement pretest of experimental and control groups

\begin{tabular}{lcccccc}
\hline Groups & $\mathrm{N}$ & $\overline{\mathrm{X}}$ & $\mathrm{Ss}$ & $\mathrm{sd}$ & $\mathrm{t}$ & $\mathrm{p}$ \\
\hline Experimental Group & 53 & 7.25 & 2.59 & \multirow{2}{*}{92} & 0.465 & 0.514 \\
Control Group & 53 & 7.02 & 2.69 & & & \\
\hline
\end{tabular}

According to Table 4 , there is a 0.23 score difference between the results that the groups obtained from the achievement test. The independent samples t-test was conducted in order to identify whether or not this difference is significant and it was observed that the difference between the groups was not significant $(\mathrm{p}=0.643>0.05)$. In other words, based on the test results, the experimental and the control groups are similar. This analysis is crucial for proving that the groups were compatible with each other at the beginning of the application. The homogeneity result of the Levene test was $\mathrm{p}=0.514>0.05$. This indicates that the experimental group and the control group have a homogeneous distribution.

The internet usage attitudes scale was conducted at the beginning of the application in order to determine the attitudes of the groups towards internet usage. The data are displayed on Table 5.

Table 5. The results of independent samples $t$ test of attitude scale towards internet usage pre test of experimental and control groups

\begin{tabular}{lccllll}
\hline Groups & $\mathrm{N}$ & $\overline{\mathrm{X}}$ & $\mathrm{Ss}$ & $\mathrm{sd}$ & $\mathrm{t}$ & $\mathrm{P}$ \\
\hline Experimental Group & 53 & 3.85 & 0.65 & \multirow{2}{*}{02} & 0.79 & \multirow{2}{*}{0.937} \\
Control Group & 53 & 3.84 & 0.64 & & &
\end{tabular}

According to the data, the experimental and control groups obtained similar results from the pre-test of the internet usage attitudes scale. An independent sample t-test was conducted in order to determine whether the 0.01 score difference is significant or not and it was observed to $b e p=0.937>0.05$. This indicates that there are no significant differences between the groups.

Data concerning the independent sample t-test which was conducted on the scores that the experimental group and control group obtained from the achievement test post-test are given on Table 6.

Table 6. The results of independent samples t test of academic achievement posttest of experimental and control groups

\begin{tabular}{lllllll}
\hline Groups & $\mathrm{N}$ & $\overline{\mathrm{X}}$ & $\mathrm{Ss}$ & $\mathrm{sd}$ & $\mathrm{t}$ & $\mathrm{p}$ \\
\hline Experimental Group & 53 & 28.21 & 1.64 & \multirow{2}{*}{75} & \multirow{2}{*}{9.075} & 0.02 \\
Control Group & 53 & 24 & 2.72 & & & \\
\hline
\end{tabular}

When the achievement test post-test scores of students who took the lectures through the mastery learning model were compared, the average score of students of the experimental group was observed to be 28.21 and average score of the students of the control group was observed to be 24. An independent sample t-test was conducted in order to determine whether the 4.21 score difference between the two groups was significant or not, and it was observed to be $\mathrm{p}=0.02<0.05$. These findings suggest that mobile portfolio assisted mastery learning model has a positive effect on the academic achievement levels of students.

Analyses concerning the final attitude scores of the experimental and control group students towards internet usage are given on Table 7. 
Table 7. The results of independent samples $t$ test of attitude scale towards internet usage posttest of experimental and control groups.

\begin{tabular}{lcccccc}
\hline Groups & $\mathrm{N}$ & $\overline{\mathrm{X}}$ & $\mathrm{Ss}$ & $\mathrm{Sd}$ & $\mathrm{T}$ & $\mathrm{P}$ \\
\hline Experimental Group & 53 & 4.04 & 3.67 & 92 & -0.453 & 0.76 \\
Control Group & 53 & 3.97 & 3.69 & & & \\
\hline
\end{tabular}

According to Table 7, the post-test score average of the experimental group regarding internet usage was 4.04 and the post-test score average of the control group was 3.97. An independent sample t-test was conducted in order to determine whether the score difference between the two groups was significant or not, and it was observed to $b e p=0.76<0.05$. It was observed that there were no significant differences between the internet usage attitudes scale scores of the experimental and control groups who were subject to the mobile portfolio assisted mastery learning model.

\section{Conclusion and Discussion}

This study was conducted on the departments of Classroom Teaching and Social Sciences Teaching and both departments were placed into the experimental and control groups. Whether or not there was a statistical difference between the academic achievement levels of the experimental group, which was subject to the mobile portfolio assisted mastery learning model, and the control group, which was subject to traditional methods, was tested and it was observed that there was a difference in favor of the experimental group. Whether or not there was a difference in the experimental group's academic achievement levels regarding the gender and department dimensions was tested and it was observed that the mobile portfolio assisted mastery learning model causes no significant differences.

Results of this study, which aimed at putting forward the effects of mobile portfolio assisted mastery learning model on the academic achievement levels of students, are parallel with the data resulting from studies conducted by Nicolaidou (2013), Kocayusuf (2013), John \& Barchock (2014). These studies suggest that the mastery learning model has positive effects on the academic achievement levels of students. Wachanga \& Gamba (2004) found that, mastery learning facilitates students learning. In the research of Damavandi\& Kashani (2010) results showed that Mastery learning is more effective for weak students. Aderemi (2006) found that using mastery learning improves positive cognitive learning outcomes in students.

Attitudes towards internet usage of the experimental group students subject to the mobile portfolio assisted mastery learning model, and the control group students, who were subject to the traditional method, were analyzed before and after the application and it was observed that the post-test scores of both groups were higher than their pre-test scores. No significant differences were detected between the groups in the analyses conducted to determine their attitudes towards internet usage. The effects of the mobile portfolio assisted mastery learning model on students' attitudes towards internet usage were observed to be similar with the effects of the traditional method. When the literature is considered, there were no studies on the effects of using portfolios or the mastery learning model on the attitudes of students on internet usage. The study conducted by Chang et al (2014) suggests that when compared with storing information in the electronic environment, creating e-portfolios have positive effects on students' attitudes. In another research De Rijdt, Tiquet, Dochy \& Devolder (2006) found that portfolio has positive effect on high education students. According to the findings of this study, mobile portfolios created by the students have positive outcomes on their attitudes towards internet usage, however the differences that emerge are not significant.

Today, it is crucial to use technology so as to increase educational quality and to raise highly qualified people. Instructional services are offered even out of school as personal computers have become more widespread (Alkan, 2011). Today individual learning has become ever more crucial and there is a wide range of ways to benefit from technology. Technology has become more widespread and mobile technologies are at top rank among the accepted technologies. By means of the internet connection opportunity and entertaining contents, mobile devices have expanded more than the other technologies. This expansion gained pace after the invention of smart mobile phones.

Based on the data of the study, it can be suggested that mobile portfolio assisted mastery learning model will lead to a significant difference in the academic achievement levels of students. With the mobile portfolio assisted mastery learning model students' academic achievement levels differ according to the department and gender variables, however, this difference is not significant. These findings are in line with the findings of the studies conducted by Chang (2014), Damavandi \& Kashani (2010) and John \& Barchok (2014)

\section{Suggestions}

Technology assisted mastery learning model will be beneficial for supporting students and it should be encouraged to be conducted in schools.

One of the most serious drawbacks that prevent mobile portfolio usage is the possibility of the students and teachers 
lacking mobile devices. One attempt that will significantly decrease this problem is the FATIH project which is implemented in Turkey by distributing tablet computers to teachers and students. This will increase the acceptance rate of mobile portfolios. Thus, teachers will get the chance to continuously follow the achievement and development levels of their students. It is suggested that creating a platform under the Ministry of National Education and integrating it with the current E-School application will be beneficial. Thus, an alternative evaluation and assessment tool will be offered in schools and student-teacher communication will be promoted after school.

Future studies can be conducted to determine the effects of the mobile portfolio assisted mastery learning model on the academic achievement, sustainability and memory levels and attitudes of secondary and high school students. Teacher opinions about the mobile portfolio assisted mastery learning model can be examined the effectiveness of this model can be identified.

\section{References}

Aderemi, D. O. (2006). Effect of Mastery Learning Approach on Students' Achievement in Mathematics Achievement Test. Unpublished Master's Thesis. University of Jos, Plateau State Nigeria.

Agca, R. K., \& Bagci, H. (2013). Egitimde Mobil Araclarin Kullanimina Iliskin Ogrenci Gorusleri (Students Views of Mobile Tools Usage in Education). Egitim ve Ogretim Arastirmalari Dergisi, 2, 295-302.

Alkan, C. (2011). Egitim Teknolojisi. Ankara: Ani Yayincilik.

Bahar, M., Nartgun, Z., Durmus, S., \& Bicak, B. (2009). Geleneksel-Tamamlayici Olcme Degerlendirme Teknikleri. Ankara: Pegem Akademi.

Bloom, B. S. (2012). Insan Nitelikleri Ve Okulda Ogrenme. (Translate: D. A. Ozcelik) Ankara: Pegem Akademi.

Brown, C. A. (2002). Portfolio Assessment: How Far Have We Come? Retrieved from https://archive.org/stream/ERIC_ED477941/ERIC_ED477941_djvu.txt), on (15th December 2016

Buyukozturk, S., Cakmak, E. K., Akgun, O. E., Karadeniz, S., \& Demirel, F. (2008). Bilimsel arastirma yontemleri. Ankara: Pegem Akademi.

Chang, C. C., Liang, C., Tseng, K. H., \& Tseng, J. S. (2014). Using e-portfolios to elevate knowledge amassment among university students. Computers \& Education, 72, 187-195. https://doi.org/10.1016/j.compedu.2013.10.015

Christophel, D. M. (1990). The relationships among teacher immediacy behaviors, student motivation, and learning. Communication education, 39(4), 323-340. https://doi.org/10.1080/03634529009378813

Damavandi, M. E., \& Kashani, Z. S. (2010). Effect of mastery learning method on performance, attitude of the weak students in chemistry. Procedia-Social and Behavioral Sciences, 5, 1574-1579. https://doi.org/10.1016/j.sbspro.2010.07.327

Davis, M. H., \& Ponnamperuma, G. G. (2005). Portfolio assessment. Journal of Veterinary Medical Education, 32(3), 279-284. https://doi.org/10.3138/jvme.32.3.279

De Rijdt, C., Tiquet, E., Dochy, F., \& Devolder, M. (2006). Teaching portfolios in higher education and their effects: An explorative study. Teaching and Teacher Education, 22(8), 1084-1093. https://doi.org/10.1016/j.tate.2006.07.002

Gloria, A., \& Oluwadara, A. (2016). Influence of Mobile Learning Training on Pre-Service Social Studies Teachers' Technology and Mobile Phone Self-Efficacies. Journal of Education and Practice, 7(2), 74-79.

Gunes, F. (2010). Egitimde Yapilandirmaci Yaklasimla Gelen Yenilikler. Egitime Bakis- Egitim-Ogretim ve Bilim Arastirma Dergisi, (16), 3-9.

Guskey, T. R. (1997). Implementing mastery learning (2nd ed.). Belmont, CA: Wadsworth Publishing Company.

International Telecommunication Union. (2014). ICT Facts And Figures. Geneva: International Telecommunication Union.

Jan, S. R., Ullah, F., Ali, H., \& Khan, F. (2016). Enhanced and Effective Learning through Mobile Learning an Insight into Students Perception of Mobile Learning at University Level. International Journal of Scientific Research in Science, Engineering and Technology (IJSRSET), 2(2), 674-681.

John, K. K., \& Barchok, H. K. (2014). Effects of Cooperative Mastery Learning Approach on Students' Motivation to learn Chemistry by Gender. Journal of Education and Practice, 91-97.

Kan, A. (2011). Olcmenin Temel Kavramlari. In: H. Atilgan (Ed.), Egitimde Olcme Ve Degerledirme (pp. 1-18). Ankara: Ani Yayincilik.

Karasar, N. (2013). Bilimsel Arastima Yontemleri. Ankara: Nobel Akademi. 
Kocayusuf, A. G. (2013). The effects of learning products of context based scenario accompanied mastery learning strategy. Unpublished Master's Thesis. Akdeniz University, Instutue of Educational Sciences, Antalya, Turkiye.

Kutlu, O., Dogan, C. D., \& Karakaya, I. (2014). Olcme Ve Degerlendirme Performansa Ve Portfolyoya Dayali Durum Belirleme . Ankara: Pegem Akademi.

MEB (The Ministry of National Education). (2009). Ilkogretim Hayat Bilgisi Ogretmen Kilavuz Kitabi. Ankara: Okyay Yayincilik.

Nicolaidou, I. (2013). E-portfolios supporting pirmary students' writing performance and peer feedback. Computers \& Education, 68, 404-415. https://doi.org/10.1016/j.compedu.2013.06.004

Oner, D., \& Adadan, E. (2016). Are integrated portfolio systems the answer? An evaluation of a web-based portfolio system to improve preservice teachers' reflective thinking skills. Journal of Computing in Higher Education, 28(2), 236-260. https://doi.org/10.1007/s12528-016-9108-y

Rani, P. (2016). Mastery Learning Using Formative Evaluation. Indian Journal of Applied Research, 6(7), 689-690.

Senemoglu, N. (2012). Gelisim Ogrenme ve Ogretim Kuramdan Uygulamaya. Ankara: Pegem Akademi.

Simon, M., \& Forgette-Giroux, R. (2000). Impact of a content selection framework on portfolio assessment at the classroom level. Assessment in Education: Principles, Policy \& Practice, 7(1), 83-100. https://doi.org/10.1080/713613325

Tavsancil, E., \& Keser, H. (2002). Internet Kullanimina Yonelik Likert Tipi Bir Olcegin Gelsitirilmesi. Egitim Bilimleri Ve Uygulama Dergisi, 79-100.

Usun, S. (2006). Bilgisayar Destekli Ogretimin Temelleri. Istanbul: Nobel Yayin Dagitim.

Wachanga, S. W., \& Gamba, P. (2004). Effects of mastery learning approach on secondary school students' achievement in chemistry in Nakuru District, Kenya. Egerton Journal of Humanities, Social Sciences and Education, 5(2), 221-235.

\section{Copyrights}

Copyright for this article is retained by the author(s), with first publication rights granted to the journal.

This is an open-access article distributed under the terms and conditions of the Creative Commons Attribution license which permits unrestricted use, distribution, and reproduction in any medium, provided the original work is properly cited. 